\title{
The Effect of Learning Models and Spatial Intelligences to Biology Learning Outcomes by Controlling the Initial Knowledge
}

\author{
Muhammad Sirih \\ Doctor Student, Graduate School of Education Technology \\ Universitas Negeri Jakarta, Indonesia \\ Nurdin Ibrahim and Priyono \\ Graduate School of Education Technology \\ Universitas Negeri Jakarta, Indonesia
}

\begin{abstract}
This research proposes to define the influence of learning designs and spatial intelligence on biology learning outcomes by controlling initial knowledge. This study was conducted at Senior High School 4 Kendari from September to December 2017. This study applies a quasi-experimental study by level $2 \times 2$. The study sample consisted of 372 students randomly selected. The data were analysed using ANCOVA and a further test with using the T-Ancova test at the 0.05 significance level. The consequences of the study indicate that: (1) Biology student learning outcomes that learned with project-based learning model are more significant than the pupils that learned with the discovery model; (2) There is an influence of the synergy among learning models and spatial intelligence on biology learning outcomes, (3) Biology learning outcomes of students with high spatial intelligence taught by project-based learning models more elevated than the students learned the discovery learning models, and (4) There are no differences in biology student learning outcomes with low spatial intelligence that learned with project-based learning model by discovery learning after controlling for initial knowledge.
\end{abstract}

Keywords: Project-based learning, discovery learning, spatial intelligence, biology learning outcomes, initial knowledge.

\section{Introduction}

Along with the times, Indonesia as part of a global community which will face global competition. Even on the scale of Asian countries in this region agree to forms of trade and economic cooperation which began in 2003, which Asia adopted a free market named the Asia Free Trade Area (AFTA). With the free market era, the Indonesian nation required to face open competition. The logical 
consequence that is the presence of Indonesian human resources was superior and sufficient in future to occupy a significant and strategic position. Their human resources to excel in mastering various skills, professional expertise, and the Indonesian science and technology will be able to move the industrial sector in a more efficient and productive and ready to compete in world markets.

One effort that can be done to prepare superior human resources and ability to compete in this global era continues to develop the condition of education. Increasing the quality of education can mainly be achieved through learning reform. The Reformation meant is the shift from traditional learning to continuous learning that sees students as not empty buckets is ready for some knowledge to him. But a child when studying in the classroom has knowledge and skills teachers should be able to facilitate with some activities that allowed to reconstruct knowledge whenever interacting with others. Learning reform includes the learning paradigm change, i.e. orientation learning model that initially centred on teachers (teacher centred) switch student-centred. Classroom activities initially didactic interactive switch, the teacher's original role as an expert turned to the position of students as experts, emphasis on teaching the unique light facts turn to the relationship between the information and findings. The concept of knowledge previously accumulated facts in quantity switch to a transformation of effects, the use of technology that was initially training and practice turning to communication, access, collaboration and expression (Arends, 2012).

Relating the statement (Arends, 2012) and along with the implementation of the 2013 curriculum in schools, the classroom learning experience observed some changes. Teachers will no longer the centre of the learning process, because of the centre learning process on the students themselves (Balım, 2009). The teacher is a facilitator that encourages learners to achieve core competence and supporting competence in some sub-themes in the learning method. The 2013 curriculum helps students to gain experience and understanding of information obtained from discovery (Setiani and Priansa, 2015). According to Minister of Education and Culture No. 81A of 2013 attachment IV, The curriculum in 2013 using a scientific approach of five learning experience that is observing, asking, reasoning, associating, communicating. The five stages are a continuous method that expected to always intersect with the realm of attitude, knowledge, and skills. During the learning process, the three domains can develop well. Students do not just know, but also can, and get a change of attitude over the learning process that is carried out (Contant and Tweed, 2017).

Based on preliminary observations and interviews with teachers of biology study conducted by researchers at Senior High School 4 Kendari, explained that Senior High School 4 Kendari 2013 curriculum implemented learning model a discovery learning. The application discovery learning model can gradually increase and arouse the curiosity of students to continue learning to find answers to the problems given by the teacher Implementation of discovery learning model wants to change the condition passive to active learning and creative (In'am and Hajar, 2017). System settings that have been teacher-centred 
learning which has become student-centred learning. Expository mode change in principle students only receives overall information from teacher to discovery mode which in principle students find information. But, its implementation in class several obstacles become problems faced by teachers in implementing discovery learning models, that students have difficulty associating the concept of which owned by the issues facing students in learning. In learning, students have not been able to find an idea that learning objectives have not achieved and students have difficulty analysing, integrate, reorganise materials and getting conclusions, as well as the necessity of creativity of pupils during the learning process.

Implications of the application of discovery learning models, seen from student learning outcomes for biology subjects in class XI MIPA in the 2014/2015 school year, i.e. $2 \%$ of students scored very good category, $31 \%$ of students get a good category, and $67 \%$ of students get enough value category. Based on the data number of students achieve the minimum criteria of competence is of $33 \%$ (minimum standards of completeness determined by school 62). While in the academic year 2015/2016, the perceived that students get the very good category $3 \%$ scores, $15 \%$ good categories, 30\% enough categories, and 52\% fewer categories. Based on these data, the number of students achieves the minimum completeness criteria of $48 \%$ with a minimum completeness criteria set school 73 (Data and information Center Senior High School 4 Kendari).

To solve the problems mentioned, the model of project-based learning is a good solution; this learning model emphasises on learning activities, student exploration, assessment, interpretation, and information synthesis to obtain various learning outcomes (knowledge, skills and attitude). Then students creative utilising the experience and own ability to do activities and produce work deem useful to themselves or others. Then after completing the project, students remember longer what they have learned, and students additionally discover how to take engagement and raise self-confidence, problem-solving, collaboratively, express ideas, and become innovators (Păvăloiu, Petrescu, and Dragomirescu, 2015)

Project-based learning model always starts with finding actual fundamental questions, which will be the basis to provide project assignments for students to activities. Next, with the help of the teacher, student groups will design activities to be carried out on respective projects (Blumenfeld et al., 2011). The greater engagement and conceptions of learners (student groups) employed in the design, the higher will be their knowledge of the plan (Afriana, Permanasari, and Fitriani, 2016). Next, instructors and pupils learn the time limit given in completing their project activities. Project-based learning models help pupils to increase their social experiences, often causes reduced defection and fewer discipline problems in class. Students also become more confident talking to groups of people, including adults (Bell, 2010). Project-based learning enhances passion for learning when children are excited and enthusiastic about what they learn; they often get more involved in the subject and then expand their interest in other items (Giri, 2016; Rabacal, Geroso, and Oliveros, 2018) 
Some studies have shown the model project-based learning positive effect on student motivation and can facilitate students' skills in problem-solving (Chiang and Lee, 2016). In research (Cawi, Marhaeni, and Dantes, 2014; Wafula and Ongunya, 2016) application based project-based learning can develop pupils' knowledge of the concept of classification of organisms influence on learning outcomes covariable drawing a layout with spatial and mathematical-logical intelligence, shows that: (1) student teaching consequences that support the project-based learning model are better than students follow conventional learning models; (2) spatial intelligence influences learning outcomes; (3) mathematical, logical intelligence influences learning outcomes; (4) spatial intelligence and mathematical-logical intelligence influence the learning outcomes; (5) Spatial intelligence provides to learning results; (6) Intelligence of logical-mathematical adds to learning results, and (7) Spatial intelligence and logical-mathematical skill contribute concurrently to learning results.

In addition, the factor to consider in the teaching and learning process is the use of learning and intelligence models that involve students, students' skills academic and knowledge related to the subject or topic discussed (Lunenberg, Korthagen, and Swennen, 2007). However, teachers do not understand the intelligence of students well will experience difficulties in the process of developing students' potential; students do not have the chance to improve their potential optimally (Anjarsari, Hobri, Irvan, and Sunardi, 2017).

Intelligence according to Gardner (2011) interpreted as an ability, with completeness process, capable handling content a specific problem in the world. However, it does not mean people have certain types of intelligence, musical intelligence, for example, will demonstrate these capabilities in every aspect of his life. It said moreover everyone nine types of intelligence in different levels. The nine model of intelligence is a verbal skill, logical intelligence, spatial intelligence, kinesthetic intelligence, musical intelligence, interpersonal skill, intrapersonal intelligence and natural intelligence, and existential intelligence. Nine types of intelligence have core components and characteristics. The presence of individual characteristics determines the level of intelligence of an individual. Students have very high intelligence can adjust more immediately than do students have low intelligence (Gardner, 2011).

In this study, researchers focused on spatial intelligence in which a person with spatial intelligence can see precisely the visual images around them and give attention to the small things that most people do not notice. One can assume that they have a great perception of power. Spatial intelligence is nearly related to biology learning in school, because biological material presents many images, schemes, graphs and diagrams that indicate students to perceive images, classify images and analogies both internal and external image, then interpret or communicate information that students understand from the picture (Armstrong, 2009; Yaumi and Ibrahim, 2016). Furthermore, McKenzie (2005) explained that spatial intelligence is the capacity to perceive the visual-spatial world accurately and make changes to perception. This intelligence introduces spatial reasoning through the use of charts, maps, tables, illustrations, art, puzzles, costumes, and 
more. Then visual intelligence allows students to draw ideas and solutions problems the student's mind before trying to verbalise or conduct in practice. While, according to (Armstrong, 2003) spatial intelligence is the capacity to know the social world accurately, perform transformations and modifications to initial perception of a person, and includes an ability to visualise aspects or visual ideas based on experience (Lohman, 1993) identifies some examples of a spatial intelligence test of a test is as follows; 1) visualisation, 2) advanced rotation, 3) closure activity, 4) closure flexibility, 5) perceptual speed. The measurement of spatial intelligence in the study focuses on classical or group analyses. Spatial ability tests generally aim to measure visual logic, imagination space/spatial, precision and accuracy someone served in the form of pictures or abstract symbols, which refers several indicators of measurement of spatial intelligence often used in research, namely:

1. Image relationship (spatial / relation); identify the same image when rotated in both two-dimensional or three-dimensional images.

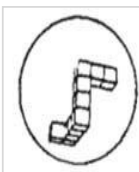

1.

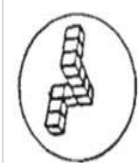

2.

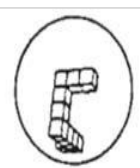

A

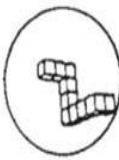

B

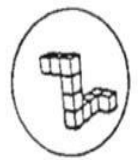

C

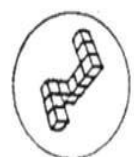

A

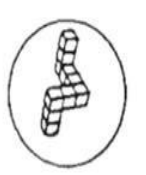

B

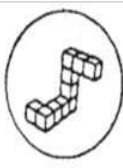

D

Figure 1. Image relationship (spasial/relation) Vandenburg and Kuse mental rotations test.

2. Spatial orientation visualises forms or abstract patterns when viewed from a different perspective.

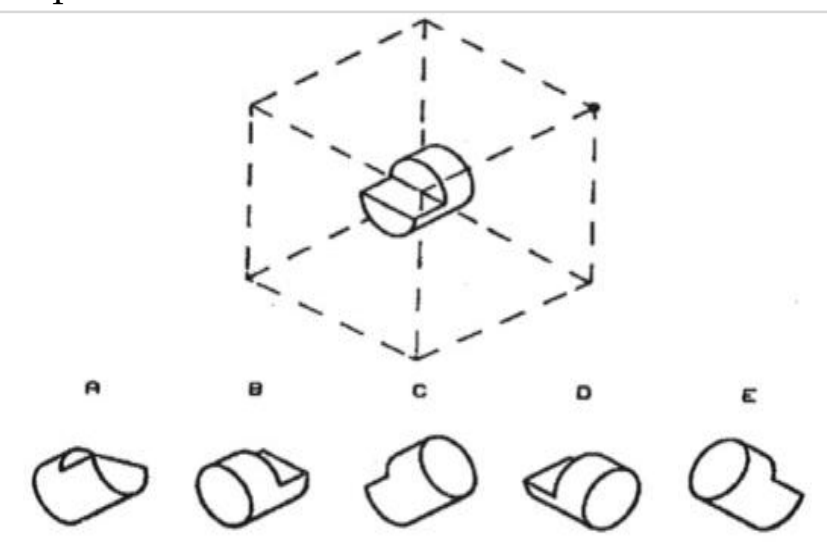

Figure 2. Image orientation test (spatial orientation) from Guay's PSVT 
3. Spatial visualisation; identifying different images from a particular group of images or based on a specific pair of images.

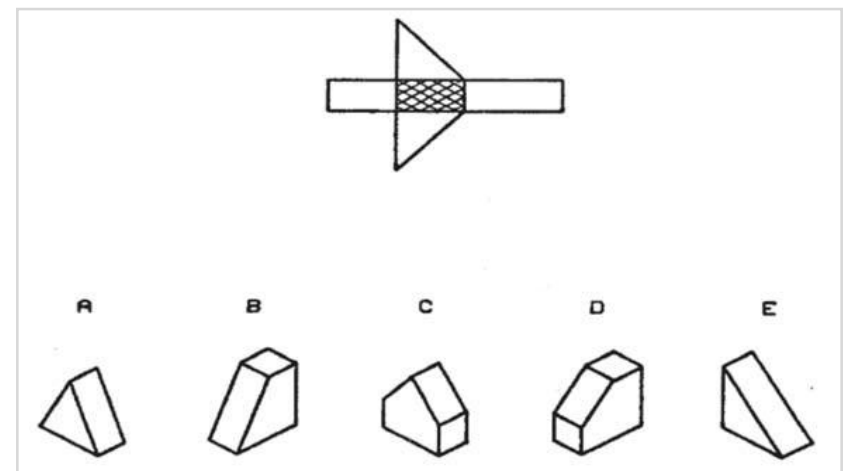

Figure 3. Visualisation test from Guay's PSVT

In this study, expanding the learning model and intelligence of individuals studied well important a teacher must know in the learning process students' prior knowledge before participating in the teaching and learning process. According (Dick, Carey, and Carey, 2014) fundamental knowledge (entry skills) is a collection of students abilities should own before they take part in a new training method. The fundamental knowledge that must be possessed by students before starting learning related to education, skills, and attitudes. Next, (Keller, 2010) identifying initial knowledge and student characteristic is vital because it will have a significant influence on the learning process. Teachers can efficiently educate students with the knowledge and skills ineligible, will have difficulty in receiving new learning material. Therefore, information about the initial experience can be used to determine to implement strategies to bridge new knowledge learned with initial knowledge.

However, the important thing how to perceive students' prior knowledge of subject matter before starting a new class. It discusses important for teachers to be able to constructivism knowledge and understanding of student characteristics related to fundamental knowledge, in addition to the teacher, determine the level of learning difficulties applied. Next (Suparman, 2012) suggested individual students' initial behaviour needs identifying because it relates to competencies, abilities or knowledge, skills, and attitudes mastered students can qualify for learning. The level of competence and characteristics of students is very various or different from each other. Characteristics expect to affect the level of success in achieving learning objectives. Based opinions, it can be assumed that basic knowledge is learning results. To find out the phenomena of both types of learning models (project-based learning and discovery learning models) on biology subjects, and how students' spatial intelligence and initial knowledge in improving student learning outcomes, it important to study with the title "Influence Learning Model (Project Based Learning and Discovery Learning) Spatial Intelligence and Biology Learning Outcomes with Initial Knowledge Controlling Students Public Senior High School 4 Kendari “. 
The goal of this study does to find out 1) Differences in biology learning outcomes between groups of students taught project-based learning and student groups learning models that discovery learning models controlling initial knowledge, 2) Interaction effect among learning models and spatial intelligence on student biology learning outcomes controlling initial knowledge, 3) Differences in biology learning results among groups of students taught project-based learning and student groups learning models discovery learning models in students have high spatial intelligence controlling initial knowledge, 4) Differences in biology learning outcomes between groups of pupils taught project-based learning models and which taught discovery learning models in students to have low spatial intelligence at controlling initial knowledge.

\section{Material and Methods}

The research techniques used in this study described as follows:

\subsection{Research Design}

This research is experimental research measured variables consisting of two main variables, namely the dependent variable and the independent variable. The dependent variable namely learning outcomes of biology in class XI MIPA Senior High School 4 Kendari Southeast Sulawesi Indonesia. The independent variable consists of two variables, namely: (1) treatment variable: learning model, composed of project-based learning and discovery learning models, and (2) moderator variable: pupils' spatial intelligence, consisting of high spatial intelligence and low spatial intelligence. The design using level $2 \times 2$ design and the experimental design of the research presented in Table 1.

Table 1. Design of experiments by the level of $2 \times 2$

\begin{tabular}{|c|c|c|}
\hline \multirow{2}{*}{$\begin{array}{c}\text { Moderator } \\
\text { variable }\end{array}$} & \multicolumn{2}{|c|}{ Variable treatment } \\
\cline { 2 - 3 } & $\begin{array}{c}\text { Project based learning } \\
\left.\text { model( } \mathrm{A}_{1}\right)\end{array}$ & $\begin{array}{c}\text { Discovery learning } \\
\left.\text { model( } \mathrm{A}_{2}\right)\end{array}$ \\
\hline $\begin{array}{c}\text { High } \\
\text { Spatial } \\
\text { Intelligence } \\
\left(\mathrm{B}_{1}\right)\end{array}$ & $\mathrm{A}_{1} \mathrm{~B}_{1}$ & $\mathrm{~A}_{2} \mathrm{~B}_{1}$ \\
{$[\mathrm{X}, \mathrm{Y}]_{11 \mathrm{k}}$} & {$[\mathrm{X}, \mathrm{Y}]_{21 \mathrm{k}}$} \\
\hline $\begin{array}{c}\text { Low Spatial } \\
\text { Intelligence } \\
\left(\mathrm{B}_{2}\right)\end{array}$ & $\mathrm{k}=1,2, \ldots, \mathrm{n}_{11}$ & $\mathrm{k}=1,2, \ldots, \mathrm{n}_{21}$ \\
& $\mathrm{~A}_{1} \mathrm{~B}_{2}$ & $\mathrm{~A}_{2} \mathrm{~B}_{2}$ \\
{$[\mathrm{X}, \mathrm{Y}]_{12 \mathrm{k}}$} & {$[\mathrm{X}, \mathrm{Y}]_{22 \mathrm{k}}$} \\
& $\mathrm{k}=1,2, \ldots, \mathrm{n}_{12}$ & $\mathrm{k}=1,2, \ldots, \mathrm{n}_{22}$ \\
\hline
\end{tabular}

Where :

$X$ : Scores of student biology initial knowledge

$\mathrm{Y}$ : Scores of student biology learning outcomes

K : Group (sample of each cell) 


\subsection{Population and Sample}

The population is all students of class XI interest in MIPA in the 2017/2018 Academic Year consisting of 9 parallel classes with 372 students.

Table 2. Population distribution

\begin{tabular}{ccc}
\hline No & Class & Total students \\
\hline 1 & Mia 1 & 41 \\
\hline 2 & Mia 2 & 41 \\
\hline 3 & Mia 3 & 41 \\
\hline 4 & Mia 4 & 41 \\
\hline 5 & Mia 5 & 41 \\
\hline 6 & Mia 6 & 42 \\
\hline 7 & Mia 7 & 42 \\
\hline 8 & Mia 8 & 42 \\
\hline 9 & Mia 9 & 41 \\
\hline & Total
\end{tabular}

The samples in this study conducted by random sampling technique. This technique used for making members of the sample of the population was random without regard to levels that survive in the population. Determination of experimental and control class done via lottery with lottery numbers one to nine. The first number came out used as the experimental class (Class XI MIA 1) and the second number that came out used as a control class (Class XI MIA 4).

Furthermore, before being given the treatment of these two classes, first given spatial intelligence tests and tests prior knowledge to the experimental class and control class to obtain data on spatial intelligence scores and initial understanding of students. Scores obtained the student in spatial intelligence test scores sorted from the lowest to the highest score. Determination of groups of students in the group with high spatial intelligence and intelligence groups using low spatial distribution of $27 \%$ for the high group and $27 \%$ for the low as samples (Sugiyono, 2015). Distribution of sample in each cell shown in Table 3.

Table 3. Sample in each cell

\begin{tabular}{ccc}
\hline $\begin{array}{c}\text { Spatial } \\
\text { Intelligence } \\
\mathbf{( B )}\end{array}$ & \multicolumn{2}{c}{ Learning models (A) } \\
\cline { 2 - 3 } & $\begin{array}{c}\text { Project-based learning }\left(\mathbf{A}_{\mathbf{1}}\right) \\
\text { (Student) }\end{array}$ & $\begin{array}{c}\left.\text { Discovery learning } \mathbf{( A}_{\mathbf{2}}\right) \\
\text { (Student) }\end{array}$ \\
\hline High $\left(\mathrm{B}_{1}\right)$ & 10 & 10 \\
\hline Low $\left(\mathrm{B}_{2}\right)$ & 10 & 10 \\
\hline Total & 20 & 20 \\
\hline
\end{tabular}

\subsection{Research procedure}

The research procedure used in this study consisted of two control classes and the experimental class. For the experimental class (A1) is given enactment with project-based learning and classroom control (A2) used with discovery learning. Next, the stages of implementing the treatment given.

A phase of preparation: The preparation phase carried out with the preparation of the lesson plan following the appropriate curriculum. Structured lesson plan 
consists of two groups: (1) Lesson Plan for the experimental group that is learning with the project-based learning and (2) Lesson Plan for the control group learning with discovery learning. In preparing the lesson plan also arranged biology instruments learning outcomes will be to the second-class treatment that is experimental class and control class. This stage carried out the preparation of spatial intelligence instrument developed by researchers through several steps: (1) review of relevant topic; (2) constructing research instruments (conceptual and operational definitions); (3) developing dimensions and indicators; (4) making lattice instruments; (5) writing items; (6) carry out construction validation and contents; (7) revise the tool; (8) conduct external validation by conducting an instrument trial on respondents outside the research sample; (9) analyze the validity and reliability of the instrument; (10) selecting items; and (10) produce a valid and reliable instrument.

A phase of implementation: In the implementation phase of the study, researchers conducted discussions with several teachers taught the topic of biology in the experimental class and the control class. The critical thinking developed in the discussion reviewing the teacher's understanding of learning with project-based learning and discovery learning. Before treatment, the two groups were given tests, namely: (1) Test of spatial intelligence to distinguish groups of students have high spatial intelligence and groups of students have to low spatial intelligence; (2) Initial knowledge test to obtain scores of students' initial knowledge in this study used as covariate variables. The treatments experimental group and the control group held several times, and each meeting of both the experimental group and the control group carried out according to the school schedule. The treatment given to the experimental group is learning with project-based learning, while treatment in the control group is learning with discovery learning

A phase of finalisation: The researchers conducted biology learning outcomes tests in both groups (experiment and control group) on the same day, hour, and duration. The learning treatment provided is using project-based learning and discovery learning in students and the time given in answering the test is 90 minutes. The procedure for the implementation of this research presented in Figure 4.

\begin{tabular}{|c|c|c|c|}
\hline \multicolumn{2}{|c|}{ Meeting 1} & Meeting 2 to 8 & Meeting 9 \\
\hline \multirow{2}{*}{$\begin{array}{c}\text { Initial } \\
\text { knowledge test }\end{array}$} & $\begin{array}{l}\text { Experiment } \\
\text { class }\end{array}$ & $\begin{array}{c}\text { Project-based } \\
\text { learning } \\
\text { model }\end{array}$ & \multirow{2}{*}{$\begin{array}{l}\text { Learning } \\
\text { outcomes }\end{array}$} \\
\hline & Control class & $\begin{array}{c}\text { Discovery } \\
\text { learning model }\end{array}$ & \\
\hline \multicolumn{2}{|c|}{ Initial knowledge test } & Treatment & Post-test \\
\hline
\end{tabular}

Figure 4. Procedure for conducting research 


\subsection{Data Collection Technique}

An instrument of learning outcomes test: Learning outcomes test instruments are used to measure the extent to which students biology learning. This type of instrument used to measure learning outcomes. Biology question made in the form of multiple choice. Each multiple-choice question equipped with five answer choices; one of the five answers is the correct answer, while the other answer choices are tricky. Each part has a score of 1 if students answer correctly and 0 if students answer incorrectly.

The instrument of spatial intelligence: Spatial intelligence instruments used to recognise between students have high intelligence and students have to low spatial intelligence. The instrument used to measure spatial intelligence is a form of multiple choice questions that equipped with five answer choices. Each item has a score of 1 if the student answers correctly and 0 if the student answers incorrectly. Measurements are made asking students as respondents to examine the pictures given in the test, and then students are invited to choose one of the images according to the test instructions that given - here grating spatial intelligence instrument as shown in Table 4.

Table 4. An instrument of spatial intelligence

\begin{tabular}{cl}
\hline Dimension & \multicolumn{1}{c}{ Indicator } \\
\hline Spatial Relation & Identify the same image if it changes because of a treatment \\
\hline $\begin{array}{c}\text { Spatial } \\
\text { Orientation }\end{array}$ & $\begin{array}{l}\text { Visualise abstract shapes and patterns when seen from a } \\
\text { different perspective }\end{array}$ \\
\hline $\begin{array}{c}\text { Spatial } \\
\text { Visualization }\end{array}$ & $\begin{array}{l}\text { Identify the various pictures of certain groups or couples } \\
\text { image }\end{array}$ \\
\hline
\end{tabular}

An instrument of initial knowledge test: The primary ability test instrument used to measure the level of material learning which must hold before the students took the subjects of biology the type of instrument used to measure students' initial knowledge is a form of multiple choice test. Each numerous choice questions equipped with five answer choices; one of the five answers is the correct answer, while the other answer choices are tricky. Each item has a score of 1 if students answer correctly and 0 if students answer incorrectly.

\subsection{Data Analysis Technique}

Data analysis assisted by SPSS.21 and Microsoft Excel 2010 software.

Descriptive analysis: Descriptive analysis used to find the mean, median, mode, standard deviation, range, maximum and minimum values. Furthermore, a frequency distribution visualised through histogram tables and graphs.

Testing requirements analysis: Test requirements for data analysis used are the normality test (Liliefors test), homogeneity test (Bartlett test), linearity test, and line alignment test.

Inferential analysis: The hypothesis testing of the study was through covariance analysis (ANCOVA). If there is an interaction between the treatment variable and the attribute variable, then further testing using the ANCOVA t-test. 


\section{Result}

Results of the descriptive analysis presented in Table 5.

Table 5. The results of the descriptive analysis

\begin{tabular}{|c|c|c|c|c|c|c|c|c|c|c|c|c|}
\hline \multirow{3}{*}{ 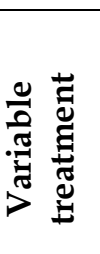 } & \multicolumn{12}{|c|}{ Data of statistic } \\
\hline & \multicolumn{2}{|c|}{$\begin{array}{c}\text { Date } \\
\text { total (n) }\end{array}$} & \multicolumn{2}{|c|}{ Average } & \multicolumn{2}{|c|}{ Median } & \multicolumn{2}{|c|}{ Minimum } & \multicolumn{2}{|c|}{ Maximum } & \multicolumn{2}{|c|}{$\begin{array}{c}\text { Standard } \\
\text { Deviation }\end{array}$} \\
\hline & $\mathbf{X}$ & $\mathbf{Y}$ & $X$ & $\mathbf{Y}$ & $X$ & $\mathbf{Y}$ & $\mathbf{X}$ & $\mathbf{Y}$ & $\mathrm{X}$ & $\mathbf{Y}$ & $\mathbf{X}$ & $\mathbf{Y}$ \\
\hline A1 & 20 & 20 & 58.82 & 76.63 & 60.29 & 76.74 & 41.18 & 67.44 & 70.59 & 88.37 & 8.15 & 6.15 \\
\hline A2 & 20 & 20 & 58.68 & 73.37 & 60.29 & 74.42 & 44.12 & 60.47 & 70.59 & 88.37 & 8.45 & 6.81 \\
\hline A1B1 & 10 & 10 & 62.94 & 79.77 & 64.71 & 80.24 & 50.00 & 69.77 & 70.59 & 88.37 & 5.92 & 5.26 \\
\hline A2B1 & 10 & 10 & 60.00 & 70.93 & 61.76 & 72.10 & 44.12 & 60.47 & 70.59 & 79.07 & 8.11 & 6.41 \\
\hline A1B2 & 10 & 10 & 54.71 & 73.49 & 54.41 & 70.93 & 41.18 & 67.44 & 67.65 & 83.72 & 8.23 & 5.50 \\
\hline A2B2 & 10 & 10 & 57.35 & 75.81 & 57.35 & 75.58 & 44.12 & 65.12 & 67.65 & 88.37 & 9.01 & 6.60 \\
\hline
\end{tabular}

The results Table 5 illustrates that the average student learning outcomes using the project-based learning model (76.63) are higher than the discovery learning model (73.37) as shown in Figure 5. The average biology learning outcomes of students taught with project-based learning are higher when compared discovery learning models in students have high spatial intelligence after controlling students' initial knowledge. While average biology learning outcomes of students taught project-based learning models and learned by discovery learning models in students, have to low spatial intelligence are almost the same value after controlling students' initial knowledge.

Table 6. The result of a hypothesis test with Ancova

\begin{tabular}{|c|c|c|c|c|c|}
\hline Source of Variance & JKy res & $\mathbf{D b}$ & $\mathbf{R J K}$ tyres & $\mathbf{F}_{\text {count }}$ & $\mathbf{F}_{\text {table }}(\boldsymbol{a}=\mathbf{0 , 0 5})$ \\
\hline Cross A & 103,08 & 1 & 103,08 & $7,74^{* *}$ & 4,13 \\
\hline Cross B & 65,73 & 1 & 65,73 & $4,94^{* *}$ & 4,13 \\
\hline Interaction (A x B) & 155,58 & 1 & 155,58 & $11,69^{* *}$ & 4,13 \\
\hline Initial knowledge (X) & 831,10 & 1 & 831,10 & $62,44^{* *}$ & 4,13 \\
\hline Inside & 452,46 & 34 & 13,31 & - & \\
\hline Total & 776,65 & 38 & - & - & \\
\hline
\end{tabular}

** $=$ significant $\left(\mathrm{F}_{\text {count }}>\mathrm{F}_{\text {table }}\right.$ to alpha 0.05$)$

ts $=$ no significant $\left(\mathrm{F}_{\text {count }}<\mathrm{F}_{\text {table }}\right)$

The results Ancova test calculation in Table 6, the source of variance between (A) are obtained $F_{\text {count }}=7,74>F_{\text {table }}=4,13$ to $a=0,05$. These shows are significant differences between biology learning outcomes of students taught project-based 
learning models (A1) with students educated with discovery learning (A2) after initial knowledge controlling.

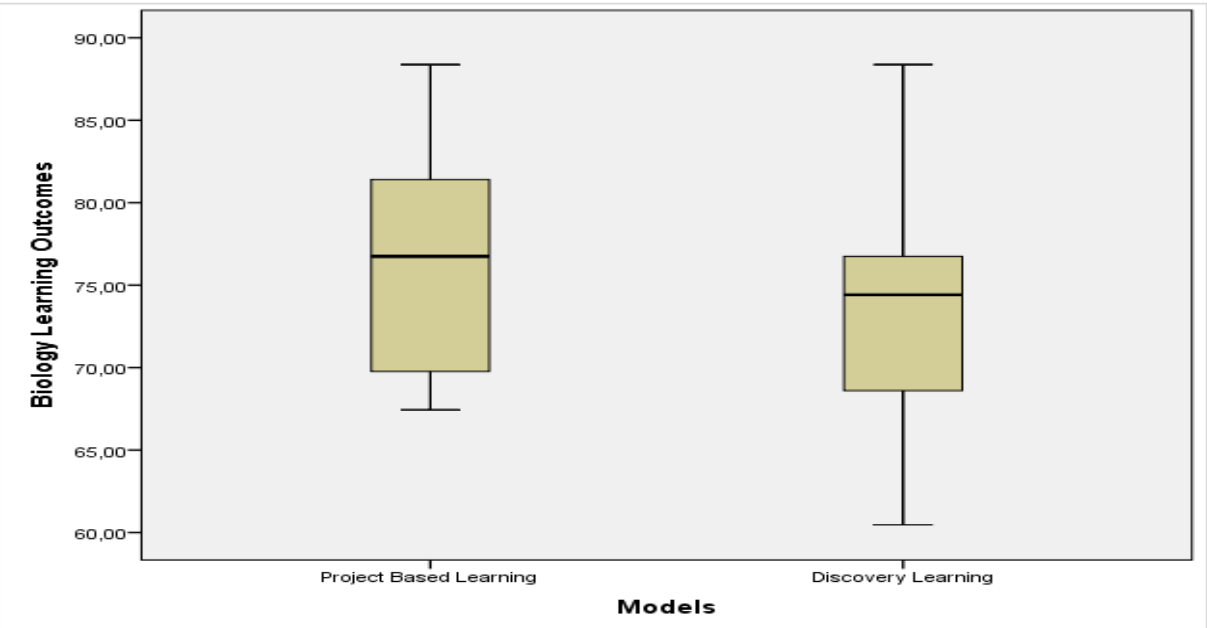

Figure 5. Boxplot graphs of biology learning results of pupils taught project-based learning and discovery learning models

The results descriptive analysis show that biology learning outcomes taught using project-based learning model in students to have high spatial intelligence after controlling initial knowledge an average of 79.77, while the biology learning outcomes of students explain discovery learning after controlling initial instruction have an average of 70.93. Student learning outcomes learned projectbased learning for students have low spatial intelligence after controlling initial knowledge have an average of 73.49, whereas student learning outcomes learned discovery leaning models after controlling initial knowledge have an average of 75.81. It Indicated that descriptively illustrates there is a cooperation influence between project-based learning and discovery learning on biology learning outcomes after controlling initial knowledge. Visually, the interaction sees in Figure 6.

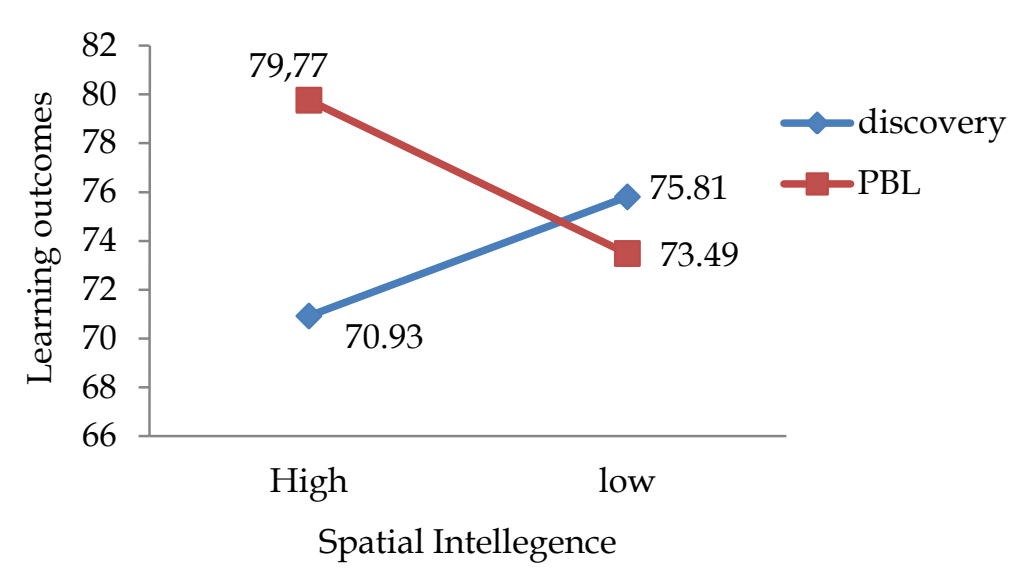

Figure 6. Graph interaction between learning models and spatial intelligence on learning outcomes of biology after controlling initial knowledge

The results ANCOVA calculations in Table 6 of AXB interaction lines are obtained $F_{\text {count }}=F_{0}(A \times B)=F_{\text {count }}=11,69>F_{\text {table }}=4,13$ to $a=0,05$. The meaning is 
an important cooperation effect among the learning model and spatial intelligence on the biology learning outcomes of students after mastering the fundamental knowledge. The shows that biology learning outcomes of students teach project-based learning for students have high spatial intelligence (A1B1) higher the biology learning outcomes of students taught direct discovery learning models (A2B1) after controlling the initial knowledge, visually can be observed in Figure 6. This result is supported by the results of further using the $T$ - Ancova test, obtained value $t_{\text {count }}=4,32>t_{\text {table }}=1,69$ to $\alpha=0,05$.

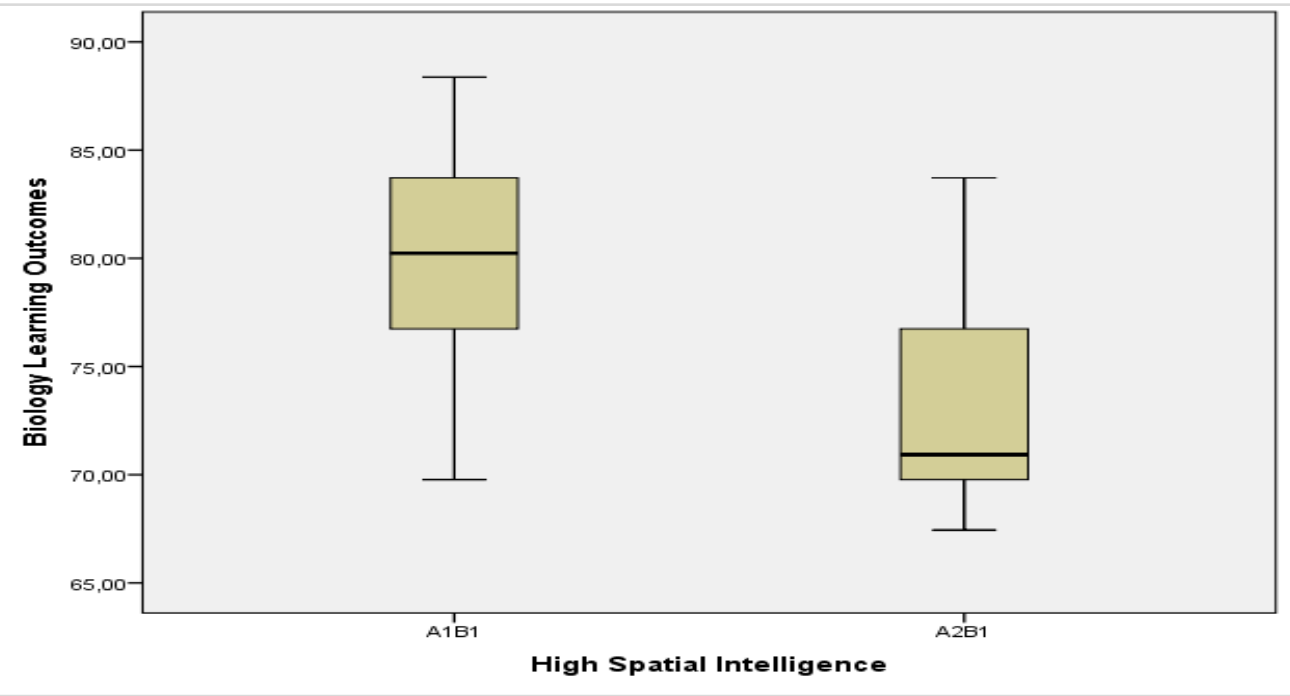

Figure 7. Biology learning results of pupils taught project-based learning and which learned discovery is learning on high spatial intelligence after controlling initial knowledge.

Furthermore, there no differences in biology learning results of pupils formed by project-based learning models and low spatial intelligence (A1B2) with students learned a model of discovery learning and low spatial intelligence (A2B2) after mastering the fundamental knowledge, visually can be seen in Figure 8 .

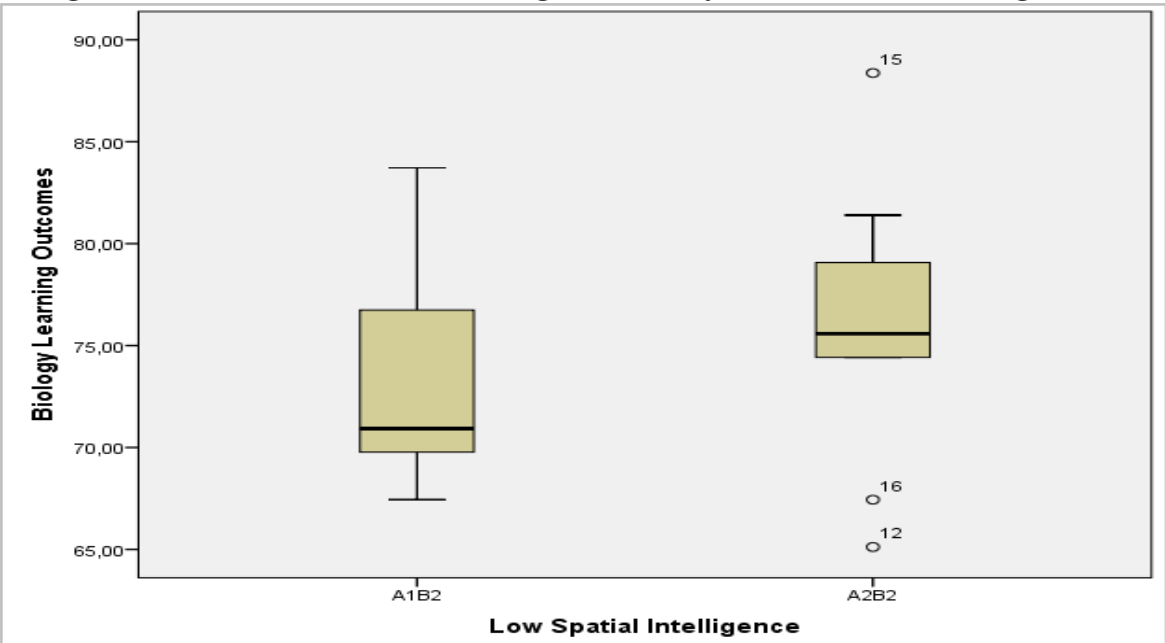

Figure 8. Biology learning results of students taught with a project-based learning model and which learned discovery learning model on low spatial intelligence after mastering fundamental knowledge

The results further tests using ANCOVA T-test, obtained value $t_{\text {count }}=0,43<$ $t_{\text {table }}=1,69$ to $a=0,05$. The improve meaning that no differences in biology 
learning results of pupils taught using the project-based learning model and discovery learning in students have low spatial intelligence after mastering fundamental knowledge.

\section{Discussion}

Based on the ANCOVA calculation as shown in Table 6, the source of variance A indicates the value of $F_{\text {count }}=7.74>F_{\text {table }(\alpha=0.05)} 1.35=4.13$. It can assume that there are variations in biology learning outcomes between groups of students taught using project-based learning (A1) with groups of students taught using discovery learning (A2) after mastering fundamental knowledge. The $F_{\text {count }}$ content obtained in testing this hypothesis comes from the effect of treatment, namely the project-based learning. The consistent with the results of studying biology in the group of students that learned using project-based learning with an average corrected $\overline{\boldsymbol{Y}}_{\text {(res)A1 }}=76,58$, while the group of students learned by using discovery learning models with corrected averages $\overline{\boldsymbol{Y}}_{\text {(res)A2 }}=73,42$. The results of calculations indicate that biology learning results among groups of pupils taught with project-based learning are higher than the group of students explained discovery learning after controlling the first knowledge.

The results of this study reinforced (Arcidiacono, Yang, Trewn, and Bucciarelli, 2016) indicated that project-based learning is a learning model based on constructivist findings, the application centred on project development as a learning tool catalysing knowledge discovery and having a significant influence on the quality and results of learning. Bagheri et al., (2013) further stated that students taught using project-based learning strategies performed better and had independent learning abilities. Project-based learning can motivate and help students to think critically in understanding knowledge more deeply to achieve the expected goals (Dias and Brantley-Dias, 2017). Furthermore, in project-based learning, students learn to become independent through goal setting, planning, and organisation; pupils improve collaboration skills within social learning; they also become intrinsically motivated to be encouraged to use the element of choice while learning at their level (Menzies, Hewitt, Kokotsaki, and Collyer, 2016)

The effect of cooperations among learning principles and spatial intelligence on biological learning results after primary knowledge control the results of ANCOVA calculations as in Table 6 source of interaction variance A $\times$ B indicate that the value of $F_{\text {count }}=11,69>F_{\text {table }}(\alpha=0.05) 1.34=4.13$, thus $H_{o}$ is rejected, and $H_{1}$ is accepted. This means that there is an impact of the interaction between the learning model (A) and spatial intelligence (B) on the learning outcomes of biology after controlling the fundamental knowledge. ANCOVA calculation data and hypothesis testing concluded that the effect of an interactive learning model and spatial toward learning outcomes after controlling for initial knowledge. This can be seen the following indications: (1) For the group of students taught by the project based learning, the biology learning results of students have high spatial intelligence (A1B1) corrected discovery learning models teach $\overline{\boldsymbol{Y}}_{\text {(res)A1B1 }}=77,21$, higher than the biology learning outcomes of students have low spatial intelligence (A1B2) with a corrected average of 
$\overline{\boldsymbol{Y}}_{\text {(res)A1B2}}=75,96$; (2) For groups of students, biology learning results of students have high spatial intelligence (A2B1) corrected on average $\overline{\boldsymbol{Y}}_{\text {(res)A2B1 }}=70,17$, lower than biology student learning outcomes that have low spatial intelligence (A2B2) with an average corrected $\overline{\boldsymbol{Y}}_{(\mathrm{res}) \mathrm{A} 2 \mathrm{~B} 2}=76,67$; (3) For groups of students have high spatial intelligence, stundent biology of learning outcomes that learned with project based learning (A1B1) having an average corrected $\overline{\boldsymbol{Y}}_{(\mathrm{res}) \mathrm{A} 1 \mathrm{~B} 1}=77,21$ greater than the Biology learning outcomes of students taught using discovery learning (A2B1) with an average corrected $\overline{\boldsymbol{Y}}_{\text {(res)A2B1 }}=70,17$; (4) For groups of students have to high spatial intelligence, biology student learning outcomes that learned with discovery learning (A1B2) have an average corrected $\overline{\boldsymbol{Y}}_{\text {(res)A1B2 }}=75,96$, lower than the biology learning results of pupils taught discovery learning (A2B2) with an average corrected $\overline{\boldsymbol{Y}}_{\text {(res)A2B2 }}=76,67$.

The results of the research mean cooperation between the learning model and the students' spatial intelligence. It can be visible from Figure 6 which shows that the biology learning results of students taught with project-based learning in students have too high spatial intelligence after controlling knowledge (A1B1) which associated with a straight line of biology learning outcomes explained project-based learning models in students have to low spatial intelligence after mastering fundamental knowledge (A1B2). Intersect with the lines that connect the learning outcomes of biology that learned by discovery learning groups of students have high spatial intelligence (A2B1), and Biology learning outcomes learned discovery is learning in groups of students have to low spatial intelligence (A2B2).

Based on the description (Table 5) shows the completion of the learning process is inseparable from the ability of the teacher to develop a learning model oriented to increase the intensity of student involvement effectively in the learning process. The accuracy of choosing a learning model aims to create learning conditions that allow students to learn actively and pleasantly so that students can achieve optimal learning outcomes and achievements. Besides, the internal situation of the student; in this case, the intelligence of the students determine their learning outcomes. The results of this study with research conducted (Sulaiman, Raub, Syrene, and Rahim, 2010) entitled:

"Teaching Strategies Based on Multiple Intelligences Theory among Science and Mathematics Secondary School Teachers"

Concluded that there was an influence of strategies/models of learning with multiple intelligence in science learning, while (Pratiwi, Rochintaniawati, and Agustin, 2018) state that managing multiple intelligences can affect learning outcomes. The evidenced by students have high spatial intelligence have higher learning outcomes compared to students have low spatial intelligence. The calculation of the T-ANCOVA test as shown in Table 6, identifies that the value of $t_{\text {count }}(A 1 B 1 ; A 2 B 1)=4.20>t_{\text {able }(\alpha=0.05)}(34)=1.69$, means that $H_{o}$ rejected, and $\mathrm{H}_{1}$ is accepted. Can be decided that there are variations in biology learning results among groups of students learned by using project-based learning with high spatial intelligence (A1B1) with groups of students being taught using discovery learning with high spatial intelligence (A2B1) after controlling initial 
knowledge. This biology learning outcomes of groups of students taught projectbased learning that has high spatial intelligence with a corrected average of $\overline{\boldsymbol{Y}}_{\text {(res)A1B1 }}=77,21$, while the group of students learned by using the discovery learning with high spatial intelligence, the average was corrected by $\overline{\boldsymbol{Y}}_{\text {(res)A2B1 }}$ $=70,17$.

The results of some calculations show (Table 6) that the project-based learning carried out in this research can develop biology learning results better than learning with discovery learning for students have high spatial intelligence after mastering fundamental knowledge. This finding answers the research hypothesis that biology learning outcomes of students are taught using projectbased learning are better than those prepared using discovery learning for students high spatial intelligence after controlling initial knowledge. The effects of this research indicate that the project-based learning model is more suitable for students to have high spatial intelligence. It is because project-based learning can improve students metacognitive skills, so students can do proper planning and can evaluate and find solutions from the planning they make, as well as contribute to students' academic achievement creating an equal learning environment (Tiantong and Siksen, 2013).

Students have high spatial intelligence able to understand what seen and student can immediately realise what is happening or what explained. Students have a basic set of intelligence, and each has a unique combination of multiple intelligences that produces a unique set of skills (Kaushik, 2017). Students have spatial, tend to think in or with images and tend to learn through visual such as movies, images, videos, and demonstrations using models and slides, and likes to draw (Jasmine, 2016). This explanation supported by the expression of (Nulhakim, Wibawa, and Erwin, 2019) that students have multiple intelligences can influence learning outcomes in the cognitive, affective or psychomotor domains.

For students have to low spatial intelligence, no difference in outcomes between the groups of students studying biology that learned using the project-based learning with a group of students that learned using discovery learning after controlling for initial knowledge. Calculation of ANCOVA t-test identification that the value of $t_{\text {count }}(A 1 B 2 ; A 2 B 2)=0.43<$ Ftable $(\alpha=0.05) 34=1.69$, meaning that $\mathrm{H}_{\mathrm{o}}$ is accepted and $H_{1}$ is rejected. Therefore it can be inferred that there is no difference in Biology learning results among groups of students are taught using project-based learning with low spatial intelligence (A1B2) with groups of students are taught using discovery with low spatial intelligence (A2B2) after mastering fundamental knowledge.

Biology learning outcomes student group that learned by using learning model project-based learning and have low spatial intelligence at $\overline{\boldsymbol{Y}}_{(\mathrm{res}) \mathrm{A} 1 \mathrm{~B} 2}=75,96$ below than the group of pupils taught by using the discovery learning with low spatial intelligence with an average corrected by $\overline{\boldsymbol{Y}}_{\text {(res)A2B2 }}=76,67$. But statistically, the difference is meaningless. Thus the hypothesis that learning outcomes biology students that learned with project-based learning are lower than students that 
learned with discovery learning for students have low spatial intelligence after controlling for initial knowledge is not proven. The absence of these differences is because the two models applied in this study are learning models that accentuate activity and creativity, inspire, fun and initiative, centered on students, authentic, contextual, and meaningful to students' daily lives (Minister of Education and Culture Number 103 Year 2014 dan Minister of Education and Culture Number 22 Year 2016). However, when viewed from the average calculation, the Biology learning results of the group of pupils developed using the project-based learning were lower than the group of students explained by using the discovery learning with low spatial intelligence. The shows that for students have low spatial intelligence it is more appropriate to apply discovery learning models. There is no difference calculation of the T-ANCOVA test because the two models employed in this study are learning models that highlight activity and creativity and are student-centred.

\section{Conclusion}

In this research, spatial intelligence an important role in determining the learning model used in biology learning, and the conclusions from this study are (1) Biology learning results of students taught with a problem-based learning model are higher than students learn with discovery learning models after controlling initial knowledge, (2) There is an impact of the cooperation among learning models and spatial intelligence on biology learning outcomes after mastering fundamental knowledge, (3) Biology pupil learning results that learned with project-based learning higher than biology student learning results that learned with the discovery learning in students have high spatial intelligence after controlling for initial knowledge, and (4) there are no differences in biology learning outcomes of students are taught project-based learning models with students taught discovery learning model in students have low spatial intelligence after controlling initial knowledge.

Recommendation for further researchers, namely (1) for students have high spatial intelligence should use to project-based learning models, (2) there needs to be further research with different learning models with student characteristics, (3) researching with different covariate variables from this study.

\section{References}

Afriana, J., Permanasari, A., \& Fitriani, A. (2016). Project-Based Learning Integrated to Stem to Enhance Elementary School's Students Scientific Literacy. Jurnal Pendidikan IPA Indonesia, 5(2), 261-267. https:// doi.org/10.15294/jpii.v5i2.5493

Akhsanul In'am, \& Hajar, S. (2017). Learning Geometry Through Discovery Learning Using a Scientific Approach. International Journal of Instruction, 10(1), 55-70. https://doi.org/10.12973/iji.2017.1014a

Anjarsari, E., Hobri, Irvan, M., \& Sunardi. (2017). Spatial Intelligence on Solving Three Dimensional Geometry Object Through Project Based Learning. Journal of Social Sciences and Humanities Invention, 4(8), 3817-3822.

Arcidiacono, G., Yang, K., Trewn, J., \& Bucciarelli, L. (2016). Application of Axiomatic Design for Project-Based Learning Methodology. Procedia CIRP, 53, 166-172. https://doi.org/10.1016/j.procir.2016.08.003

Arends, R. I. (2012). Learning to Teach (Ninth Edition). New York: McGraw-Hill Education. 
Armstrong, T. (2003). The Multiple Intelligences of Reading and Writing: Making the Words Come Alive. Alexandria: Association for Supervision and Curriculum Development (ASCD).

Armstrong, T. (2009). Intelligence Multiple in the Classroom: Educational Research (3edition). Virginia USA: Assn for Supervision \& Curriculum.

Bagheri, M., Branch, N., Daud, S. M., Zah, W., Ali, W., \& Chong, A. M. (2013). ProjectBased Learning as a Facilitator to Promote Students' Technology Competencies. World Journal on Educational Technology, 5(April), 207-214.

Balım, A. G. (2009). The Effects of Discovery Learning on Students' Success and Inquiry Learning Skills. Eurasian Journal of Educational Research, 6(35), 1-20.

Bell, S. (2010). Project-Based Learning for the 21st Century: Skills for the Future. The Clearing House, 83(2), 39-43. https:/ / doi.org/10.1080/00098650903505415

Blumenfeld, P. C., Soloway, E., Marx, R. W., Krajcik, J. S., Guzdial, M., Palincsar, A., Palincsar, A. (2011). Motivating Project-Based Learning: Sustaining the Doing, Supporting the Learning. Educational Psychologist, 1520(26), 3-4. https://doi. org/10.1080/00461520.1991.9653139

Cawi, I. W., Marhaeni, A. A. I. N., \& Dantes, G. R. (2014). Pengaruh Model Pembelajaran Berbasis Projek Terhadap Hasil Belajar Menggambar Layout dengan Kovariabel Kecerdasan Spasial dan Kecerdasan Logis Matematis [The Effects of Project-Based Learning Models on Learning Outcomes Drawing Layouts with Covariables Spatial Intelligence and Mathematical Logical Intelligence]. E-Journal Program Pascasarjana Universitas Pendidikan Ganesha Program, 4(2), 1-11.

Chiang, C. L., \& Lee H. (2016). The Effect of Project-Based Learning on Learning Motivation and Problem-Solving Ability of Vocational High School Students. International Journal of Information and Education Technology, 6(9), 709-712. https://doi.org/10.7763/IJIET.2016.V6.779.

Contant, T. L., \& Tweed, A. L. (2017). Teaching Science Through Inquiry-Based Instruction (13 Edition). USA: Pearson Education, Inc.

Dias, M., \& Brantley-Dias, L. (2017). Setting the Standard for Project Based Learning: A Proven Approach to Rigorous Classroom Instruction. Interdiciplinary Journal of Problem Based Learning, 11(2), 1-4. https:// doi.org/10.7771/1541-5015.1721

Dick, W., Carey, L., \& Carey, J. O. (2014). Systematic Design of Instruction (8 Edition). USA: Pearson Education, Inc.

Giri, D. R. (2016). Project-Based Learning as 21st Century Teaching Approach: A Study in Nepalese Private Schools. US-China Education Review A, 6(8), 487-497. https:// doi.org/10.17265/2161-623X/2016.08.004

Gardner, H. (2011). Howard Gardner Theory Multiple Intelligences (Tentt-anni). New York: Basic Books.

Jasmine, J. (2016). Metode Mengajar Multiple Intelligence [Teaching Multiple Intelligence Methods]. Bandung: Nuansa Cendekia.

John M. Keller. (2010). Motivational Design for Learning and Performance: The ARCS Model Approach. USA: Springer SciencepBusiness Media. https://doi.org/10.1007/978-14419-1250-3

Kaushik, P. (2017). Redefining Learning: Kolb's Theory of Learning Styles with Gardner's. International Journal of Learning and Teaching, 09(1), 330-339. https:// doi.org/10.18844/ijlt.v8i5.1889

Lohman, D. F. (1993). Spatial Ability and G. The University of Iowa, pp. 1-19. Retrieved from https://pdfs.semanticscholar.org/5fa3/456fcf0c3f16b4db2b49e10b3443461f22 09

Lunenberg, M., Korthagen, F., \& A Swennen. (2007). The Teacher Educator as A Role Model. Teaching and Teacher Education, 23(5), 586-601.

McKenzie, W. (2005). Multiple Intelligences and Instructional Technology (Second Edi). Washinton: Internasion Society for Technology in Education. 
Menzies, V., Hewitt, C., Kokotsaki, D., \& Collyer, C. (2016). Project-Based Learning Evaluation Report and Executive Summary. Durham: Education Endowment Foundation. Retrieved from https://eric.ed.gov/?id=ED581257

Nulhakim, L., Wibawa, B., \& Erwin, N. (2019). Relationship Between Students ' Multiple Intelligence-Based Instructional Areas and Assessment on Academic Achievements. IOP Conf. Series: Journal of Physics, 1188(012086), 1-7. https://doi. org/10.1088/ 1742-6596/1188/1/012086

Păvăloiu, I.-B., Petrescu, I., \& Dragomirescu, C. (2015). Interdisciplinary Project-based Laboratory Works. Procedia - Social and Behavioral Sciences, 180(November 2014), 1145-1151. https:// doi.org/10.1016/j.sbspro.2015.02.230

Pratiwi, W. N., Rochintaniawati, D., \& Agustin, R. R. (2018). The Effect of Multiple Intelligence-Based Learning Towards Students' Concept Mastery and Interest in Learning Matter. IOP Conf. Series: Journal of Physics, 1013(012075), 1-7. https:// doi.org/10.1088/1742-6596/1013/1/012075

Rabacal, J. S., Geroso, M. J. S., \& Oliveros, J. A. (2018). Developing Students 21 Century Skills Using Project Based Learning. Asia Pacific Journal of Multidisciplinary Research, 6(2), 47-53.

Setiani, A., \& Priansa, D. J. (2015). Manajemen Peserta Didik dan Model Pembelajaran: Cerdas, Kreatif, dan Inovatif [Learner Management and Learning Models: Smart, Creative and Innovative]. Bandung: Alfabeta.

Sugiyono. (2015). Metode Penelitian Kuantitatif, Kualitatif dan $R \& D$ [Quantitative, Qualitative Research, $R \& D$ Methods]. Bandung: Alfabeta.

Sulaiman, T., Raub, A., Syrene, S., \& Rahim, A. (2010). Teaching Strategies Based on Multiple Intelligences Theory among Science and Mathematics Secondary School Teachers. Procedia Social and Behavioral Sciences, 8, 512-518. https://doi.org/10.1016 /j.sbspro.2010.12.070

Suparman, M. A. (2012). Desain Instruksional Modern: Panduan Pengajar dan Innovator Pendidikan [Modern Instructional Design: Teacher's Guide and Educational Innovator]. Jakarta: Penerbit Erlangga.

Tiantong, M., \& Siksen, S. (2013). The Online Project-Based Learning Model Based on Student's Multiple Intelligence. International Journal of Humanities and Social Science, 3(7), 204-211.

Wafula, W. N., \& Ongunya, R. O. (2016). Project Based Learning on Students' Performance in the Concept of Classification of Organisms among Secondary Schools in Kenya. Journal of Education and Practice, 7(16), 25-31.

Yaumi, M., \& Ibrahim, N. (2016). Pembelajaran Berbasis Kecerdasan Jamak (Multiple Intelligences) Mengidentifikasi dan Mengembangkan Multitalenta Anak (Cetakan 1) [Multiple Intelligence Based Learning Dentifies and Develops Multitalented Children]. Jakarta: Kencana Prenadamedia Group. 